\title{
Holliday junction-recognition protein modulates apoptosis, cell cycle arrest and reactive oxygen species stress in human renal cell carcinoma
}

\author{
JIANG-SHUI YUAN ${ }^{1,2}$, ZENG-SHENG CHEN $^{1,2}$, KE WANG $^{3}$ and ZONG-LIANG ZHANG ${ }^{3}$ \\ ${ }^{1}$ Department of Clinical Laboratory, Qingdao Municipal Hospital, Qingdao, Shandong 266011; \\ ${ }^{2}$ Department of Clinical Laboratory, Third Clinical College, Qingdao University, Qingdao, Shandong 266071; \\ ${ }^{3}$ Department of Urology, Affiliated Hospital of Qingdao University, Qingdao, Shandong 266003, P.R. China
}

Received July 24, 2019; Accepted April 29, 2020

DOI: $10.3892 / o r .2020 .7656$

\begin{abstract}
Holliday junction recognition protein (HJURP) is involved in the regulation of mortality in various cell types, including renal cell carcinoma (RCC) cells. The specific mechanisms by which HJURP regulates RCC cell apoptosis and the cell cycle have not been previously investigated, to the best of our knowledge. In the present study, the expression of HJURP in RCC tissues and adjacent paracancerous renal tissue, as well as in RCC cell lines, was analyzed using reverse transcription-quantitative PCR and western blot analysis. The A498 RCC cells were transfected with an HJURP overexpression vector, which resulted in reduced proliferation, as demonstrated using immunofluorescence staining, a Cell Counting Kit-8 assay and a colony formation assay. Flow cytometry and terminal deoxynucleotidyl transferase deoxyuridine triphosphate nick end labelling assays were used to determine the effect of HJURP on the cell cycle and apoptosis of RCC cells. Proteins associated with the reactive oxygen species (ROS) status were analyzed using western blot analysis. The expression of HJURP was lower in RCC tissues and cells compared with that in the adjacent paracancerous renal tissues and control cells. Furthermore, overexpression of HJURP resulted in a decrease in cell viability and proliferation in vitro. Overexpression of HJURP resulted in cell cycle arrest at the G0/G1 phase, cell apoptosis and an increase in ROS stress. In addition, the phosphorylated/total sirtuin 1 (SIRT1) protein ratio was decreased, whereas the expression of peroxisome proliferator-activated receptor (PPAR) $\gamma$ was increased in the HJURP-overexpressing RCC cells. In clinical
\end{abstract}

Correspondence to: Professor Ke Wang or Professor Zong-Liang Zhang, Department of Urology, Affiliated Hospital of Qingdao University, 16 Jiangsu Road, Qingdao, Shandong 266003, P.R. China E-mail: wangke6910@sina.com

E-mail: zzl_qdslyy@163.com

Key words: Holliday junction recognition protein, apoptosis, renal cell carcinoma, cell cycle practice, decreased HJURP expression may be associated with poor prognosis in patients with RCC. These results suggest that HJURP may regulate cell apoptosis and proliferation in RCC cells and this may be mediated by PPAR $\gamma /$ SIRT1. Thus, HJURP may be used as a predictor of prognosis in patients with RCC.

\section{Introduction}

Renal cell carcinoma (RCC) accounts for 3-5\% of all cancer diagnoses worldwide (1). The incidence rate of RCC has been increasing annually, and at present, $\sim 20 \%$ of newly diagnosed RCC cases result in death. RCC is one of the leading causes of cancer-associated death worldwide, according to the World Health Organization (WHO) (2) and 20-30\% of patients with RCC present with metastases at the initial diagnosis (2). Due to the limitations of current treatment methods, which may result in the development of resistance to chemoradiotherapy, as well as the difficulty of radical resection, novel therapeutic targets are required to improve outcomes of patients with RCC. Wei et al (3) demonstrated that the expression levels of certain hub genes [CDKN3, TPX2, BUB1B, CDCA8, UBE2C, NDC80, RRM2, NCAPG, NCAPH,PTTG1,FAM64A, ANLN, KIF4A, CEP55, centromere protein (CENP)-F, KIF20A, ASPM and Holliday junction recognition protein (HJURP)] were significantly associated with overall survival and recurrence-free survival in RCC (3). In recent years, HJURP has been demonstrated to involve in the cell viability and cell cycle in numerous types of human tumor (4-7). However, the mechanism of HJURP in RCC has remained elusive. Therefore, in the present study, HJURP was selected as the research subject to investigate its role in the development of RCC.

HJURP, also known as hFLEG1, is a histone chaperone in the nucleosome, which recruits CENP-C and CENP-A $(5,6)$. HJURP has been indicated to regulate chromosomal stability and amplification of the centromere $(7,8)$. HJURP is also involved in the accurate segregation of chromosomes during mitosis. HJURP binds directly to soluble CENP-A, stabilizing it and regulating its binding to centromeres during the G1 phase of the cell cycle (9). HJURP is upregulated by ataxia telangiectasia-mutated signaling during a DNA double-strand 
break response and participates in the homologous recombination pathways during repair of double-stranded breaks (4). Downregulation of HJURP levels results in a significant reduction of CENP-A levels at centromeres, which may affect centromere assembly and microtubule attachment, and may thus underlie defects in chromosome segregation during mitosis (10-12).

Valente et al (13) demonstrated that the upregulation of HJURP expression may serve an important role in the survival of cells with a high degree of proliferative activity in high-grade malignancy gliomas. Furthermore, HJURP has been demonstrated to be involved in cell viability and the cell cycle in lung carcinoma (4), breast carcinoma (14), bladder cancer (15) and hepatocellular carcinoma (16), and may be a novel and important prognostic indicator involved in the development and progression of several types of cancer (17-19).

Peroxisome-proliferator-activated receptors (PPARs) are nuclear receptors that regulate tumor growth $(20,21)$. Activation/deactivation of PPARs may affect the expression of genes associated with cellular metabolism, proliferation, lipid peroxidation and stress responses, including reactive oxygen species (ROS) (22). The nuclear receptor PPAR $\gamma$, a key member of the PPAR family, is involved in cell cycle regulation $(23,24)$, where it binds to the promoter region of sirtuin (SIRT)1 to regulate its transcription (25). SIRT1 functions as a key regulator of genes regulating apoptosis and cell survival, including PPAR $\gamma$ (26) and p53 (27). The association between PPAR $\gamma$ and SIRT1 and the presence of a negative feedback loop between PPAR $\gamma /$ SIRT1 has been previously reported (25).

Tumor cells are characterized by an accumulation of mutations that drive tumor development and progression, including changes in the number of copies of chromosomes, chromosomal rearrangements, point mutations and small deletions and insertions (28-30). Although the association between RCC and HJURP has not been previously demonstrated, to the best of our knowledge, preliminary results by our group indicated that HJURP participates in the regulation of the cell cycle and cell apoptosis in RCC. Thus, it was hypothesized that changes in HJURP expression levels may serve an important role in the regulation of cell viability and the cell cycle of RCC cells. In the present study, HJURP expression levels were determined and the expression of ROS-associated genes was detected in RCC tissues; furthermore, the roles of HJURP were assessed in vitro using RCC cell lines.

\section{Materials and methods}

Patients. RCC tissue samples $(\mathrm{n}=15)$ and adjacent paracancerous renal tissue samples $(n=15)$ were obtained from patients who underwent radical resection at the Affiliated Hospital of Qingdao University (Qingdao, China). The age of the subjects ranged from 35 to 76 years with a median age of 56 years, including 10 males and 5 females. These samples were immediately stored in liquid nitrogen following surgical removal for further analysis. All patients provided written informed consent and the diagnosis of RCC was determined according to the WHO criteria (31). The Medical Ethics Committee at the Affiliated Hospital of Qingdao University (Qingdao, China) approved the use of human RCC tissue samples for protein analysis and RNA extraction (approval no. 201801), and all experiments involving the RCC tissue samples were performed in accordance with the criteria approved by the Ethics Committee.

Cell culture. The RCC cell lines A498 (KG414) and Caki-1 (KG211), as well as the renal tubular epithelial cell line HK2 (KG350), were purchased from Nanjing KeyGen Biotech Co., Ltd. The A498 and Caki-1 cells were cultured in RPMI-1640 medium (Gibco; Thermo Fisher Scientific, Inc.), while HK2 cells were cultured in Dulbecco's modified Eagle's medium (Gibco; Thermo Fisher Scientific, Inc.) supplemented with $100 \mathrm{U} / \mathrm{ml}$ penicillin, $0.1 \mathrm{mg} / \mathrm{ml}$ streptomycin and $10 \%$ fetal bovine serum (Gibco; Thermo Fisher Scientific, Inc.). Cells were maintained in a humidified incubator with $5 \% \mathrm{CO}_{2}$ at $37^{\circ} \mathrm{C}$.

Reverse transcription-quantitative (RT- $q P C R)$ analysis. RNA was extracted from A498 cells, Caki-1 cells and RCC tissues using TRIzol ${ }^{\circledR}$ (Invitrogen; Thermo Fisher Scientific, Inc.) according to the manufacturer's protocol. Complementary DNA synthesis was performed using oligo(dT), MLV Reverse Transcriptase, Reverse Transcription 5X Buffer and dNTP Mixture (10 mM each dNTP) according to the manufacturer's protocol (Takara, Bio, Inc.) after RNA was treated with DNAse I (Sangon Biotech, Co., Ltd.) and RNAse inhibitor (Invitrogen; Thermo Fisher Scientific, Inc.). The SYBR Green I Real-Time PCR kit (Takara Bio, Inc.) was used to perform qPCR according to the manufacturer's protocol and the amplification was performed in an ABI Prism 7500 (Perkin-Elmer, Inc.). The following thermocycling conditions were used for the qPCR: 40 cycles of $95^{\circ} \mathrm{C}$ for $15 \mathrm{sec}, 60^{\circ} \mathrm{C}$ for $20 \mathrm{sec}$ and $72^{\circ} \mathrm{C}$ for $40 \mathrm{sec}$. The expression was normalized to GAPDH. The sequences of the primers used were as follows: HJURP forward, 5'-CCGCAGCAGACATCTGACCTTC-3' and reverse, 5'-TCCGTGGCCTGGCACTTCTT-3'; and GAPDH forward, 5'-AGATCATCAGCAATGCCTCCT-3' and reverse, 5'-TGAGTCCTTCCACGATACCAA-3'. The mRNA expression levels were calculated using the $2^{-\Delta \Delta \mathrm{Cq}}$ method (32).

Western blot analysis. RCC tissue samples and adjacent paracancerous renal tissue samples were homogenized in $150 \mathrm{U} / \mathrm{ml}$ DNase I buffer in $5 \mathrm{mmol} / 1 \mathrm{MgCl}_{2}, 1 \mathrm{mmol} / 1 \mathrm{CaCl}_{2}$ and $20 \mathrm{mmol} / 1$ Tris- $\mathrm{HCl}$ (pH 6.8; Takara Bio, Inc.). Cells were sonicated and lysed in radioimmunoprecipitation assay lysis buffer supplemented with protease and phosphatase inhibitors (Nanjing KeyGen Biotech Co., Ltd.) for $15 \mathrm{~min}$ at $4^{\circ} \mathrm{C}$. The solution was centrifuged at $14,000 \mathrm{x}$ for $15 \mathrm{~min}$ at $4^{\circ} \mathrm{C}$ and the supernatant was collected. The concentrations of proteins were determined using a bicinchoninic acid assay kit (Nanjing KeyGen Biotech Co., Ltd.), with bovine serum albumin (BSA) used as the standard (Nanjing KeyGen Biotech Co., Ltd.). Proteins $(10 \mu \mathrm{g})$ were loaded on a $10 \%$ SDS gel, resolved using SDS-PAGE and transferred to polyvinylidene difluoride membranes (Nanjing KeyGen Biotech Co., Ltd.). Membranes were blocked in 5\% BSA for $2 \mathrm{~h}$ at room temperature. Subsequently, membranes were incubated with primary antibodies, including those to HJURP (1:2,000; cat. no. ab100800; Abcam), catalase (1:10,000; cat. no. ab76024; Abcam), superoxide dismutase (SOD)2 (1:1,000; cat. no. ab68155; Abcam), PPAR $\gamma$ (1:1,000; 
A

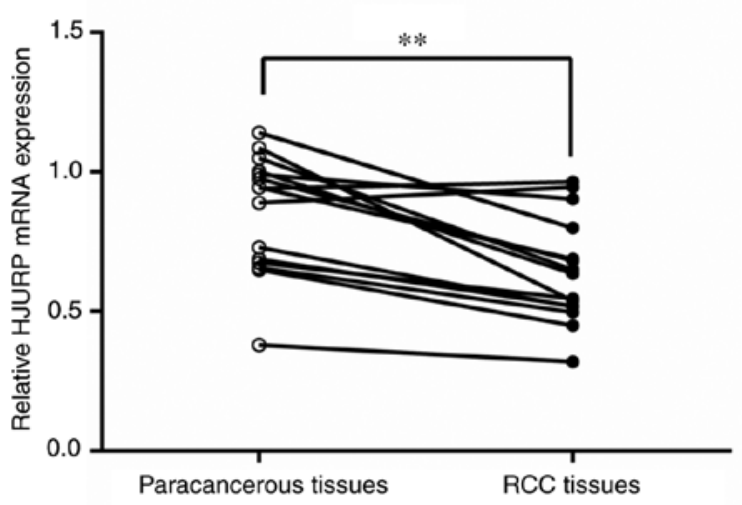

C

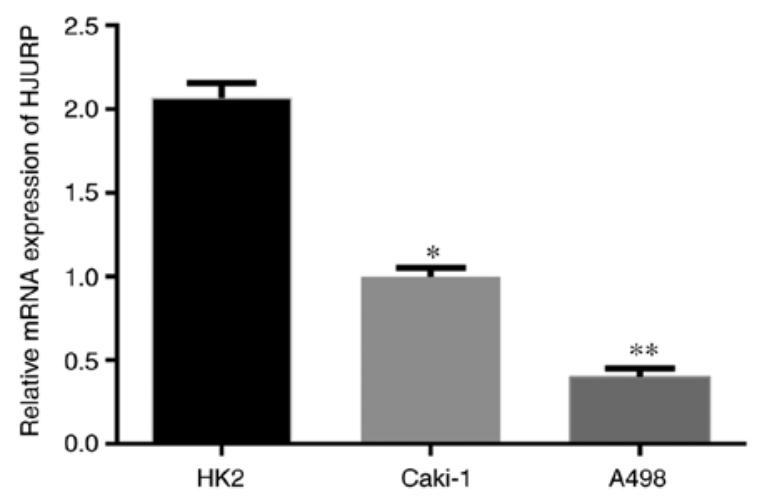

B

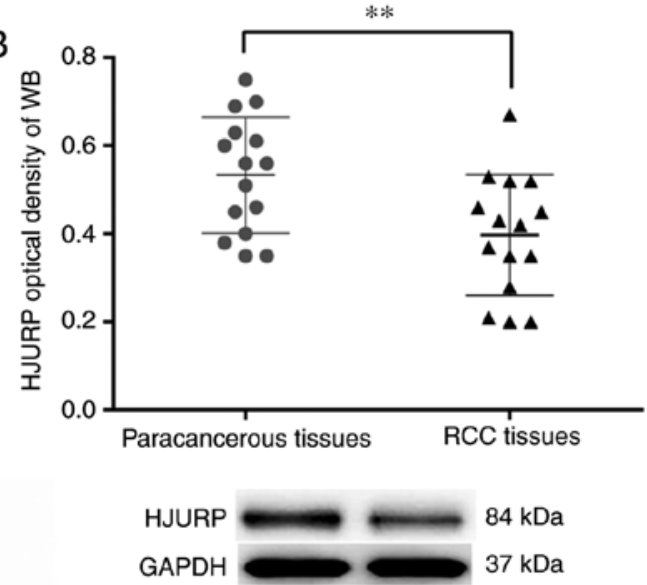

D

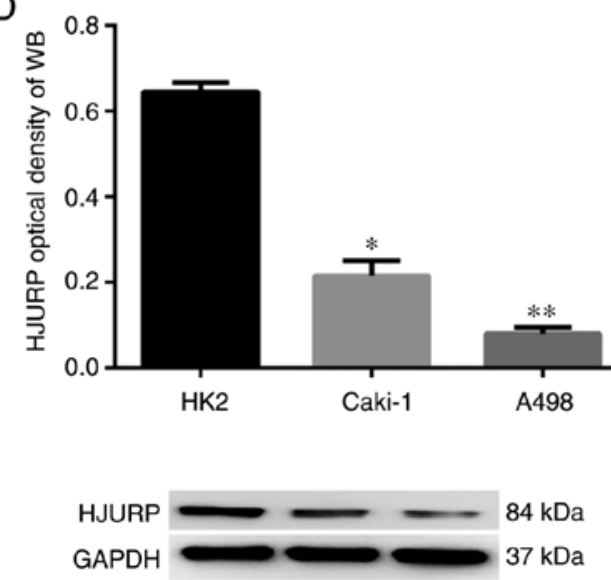

Figure 1. Downregulation of HJURP in RCC tissues. (A) The mRNA expression levels of HJURP in RCC tissues were significantly lower compared with the control tissues. (B) The protein expression levels of HJURP in RCC tissues compared with the control paracancerous tissues. ${ }^{* *} \mathrm{P}<0.01$ as indicated. (C) mRNA expression levels of HJURP was significantly decreased in RCC cell lines compared with that in renal tubular epithelial cells. (D) HJURP protein expression in RCC cell lines compared with the control group. ${ }^{*} \mathrm{P}<0.05,{ }^{* *} \mathrm{P}<0.01$ vs. HK2. HJURP, Holliday junction recognition protein; RCC, renal cell carcinoma.

cat. no. ab59256; Abcam), phosphorylated (p)-SIRT1 (1:1,000; cat. no. ab76039; Abcam), SIRT1 (1:1,000; cat. no. ab110304; Abcam), forkhead box (FOX)O3a (1:100; cat. no. BM4734; Wuhan Boster Biological Technology, Ltd.), p-FOXO3a (1:1,000; cat. no. ab154786; Abcam) and cyclin D1 (CCND1; 1:1,000; cat. no. ab40754; Abcam) overnight at $4^{\circ} \mathrm{C}$, followed by horseradish peroxidase-labeled secondary antibody $(1: 10,000$; cat. no. KGAA35; Nanjing KeyGen Biotech Co., Ltd.) for $1 \mathrm{~h}$ at room temperature. GAPDH (1:3,000; cat. no. K200057M; Solarbio Life Science) was selected as the loading control. As GAPDH and CCND1 have a similar molecular weight, the same specimen was added to two different gels, electrophoresis was performed on the same apparatus and labeling with the antibodies was performed separately. Signals were visualized using enhanced chemiluminescence reagent (Bio-Rad Laboratories, Inc.) and bands were imaged using a G:BOX chemiXR5 system (Syngene Europe).

Overexpression of HJURP in RCC cells. A pcDNA3.1(+)-HJURP vector was synthesized by Nanjing KeyGen Biotech Co., Ltd. The A498 RCC cells (2,000 cells/well) were plated in 96-well plates and pcDNA3.1(+)-HJURP vector were introduced into cells using Oligofectamine (Invitrogen; Thermo Fisher Scientific, Inc.). Cells were fixed and processed for the subsequent experiment $72 \mathrm{~h}$ after transfection. The A498 RCC cells were transfected with the pcDNA3.1(+)-HJURP vector to increase the mRNA expression levels of HJURP (A498 HJURP $\mathrm{OE})$. The A498 cells were used as the control group and the A498 cells transfected with pcDNA3.1(+) were used as a negative control (A498 NC).

Immunocytochemistry. Cells were washed three times with cold PBS and fixed in $4 \%$ paraformaldehyde for $30 \mathrm{~min}$ at room temperature. RCC cells were placed in $3 \% \mathrm{H}_{2} \mathrm{O}_{2}$-methanol solution (Nanjing KeyGen Biotech Co., Ltd.) for $10 \mathrm{~min}$ at room temperature, washed in PBS and blocked in standard goat serum (Nanjing KeyGen Biotech Co., Ltd.) at room temperature for 20 min. Following blocking, cells were incubated with the HJURP primary antibody (1:100; cat. no. ab100800, Abcam) for $2 \mathrm{~h}$ at $37^{\circ} \mathrm{C}$, washed using PBS and subsequently incubated with FITC-labeled secondary antibody (1:100; cat. no. BA1105; BosterBiological Technology) for $1 \mathrm{~h}$ at $37^{\circ} \mathrm{C}$. To visualize the nuclei, cells were stained with DAPI $(2 \mu \mathrm{g} / \mathrm{ml})$ for $5 \mathrm{~min}$ at room temperature. Immunofluorescence staining was observed using a fluorescence microscope (x200 magnification).

Cell Counting Kit-8 (CCK-8) assay. RCC cells were collected $\left(5 \times 10^{4}\right.$ cells $\left./ \mathrm{ml}\right)$ following transfection for $48 \mathrm{~h}$ and seeded 

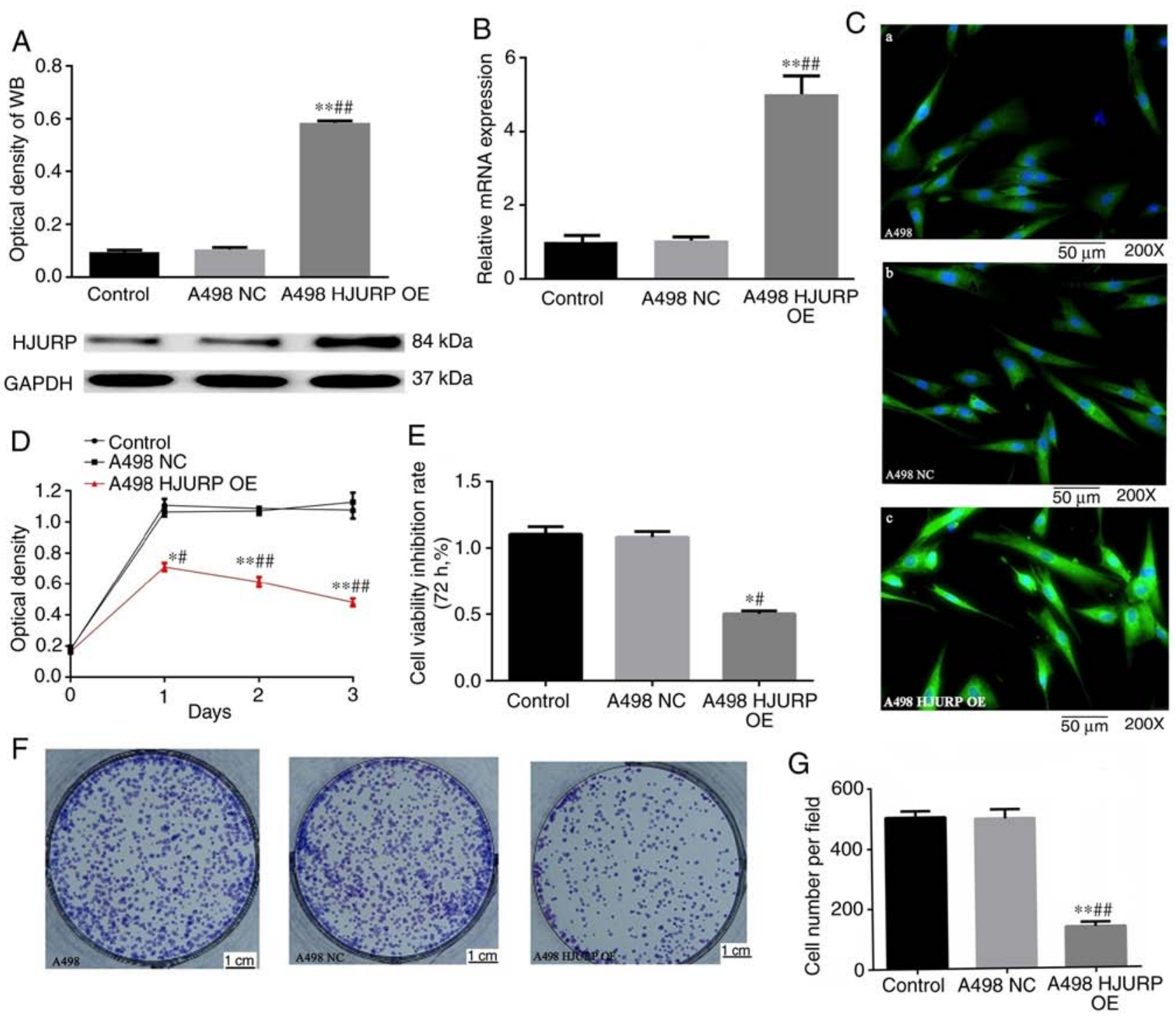

Figure 2. Overexpression of HJURP reduces RCC cell proliferation. (A) Protein and (B) mRNA expression levels of HJURP in A498 RCC cells transfected with HJURP overexpression vector or the control vector. (C) Representative immunofluorescence staining of HJURP (green) in (a) untransfected RCC cells and cells transfected with (b) control vector and (c) HJURP overexpression vector. DAPI (blue) was used for nuclear staining (scale bar, $50 \mu \mathrm{m}$; magnification, x200) (D) Viability of RCC cells transfected with HJURP overexpression vector or the control vector were detected using a Cell Counting Kit-8 assay. (E) Cell viability inhibition rate was also detected after $72 \mathrm{~h}$ using Cell Counting Kit-8 assay. (F) Colony formation was assessed in cells transfected with HJURP overexpression vector or the control vector (scale bar, $1 \mathrm{~cm}$ ). (G) Quantitative analysis of the colony formation assay. ${ }^{*} \mathrm{P}<0.05,{ }^{* *} \mathrm{P}<0.01 \mathrm{vs}$. control and ${ }^{\sharp} \mathrm{P}<0.05$, ${ }^{\# \#} \mathrm{P}<0.01$ vs. A498 NC. HJURP, Holliday junction recognition protein; RCC, renal cell carcinoma; OE, overexpression; NC, negative control.

in 96-well plates and cultured for $72 \mathrm{~h}$. Subsequently, $10 \mu \mathrm{l}$ CCK-8 solution $(5 \mathrm{mg} / \mathrm{ml})$ was added to each well and cells were incubated at $37^{\circ} \mathrm{C}$ for $2 \mathrm{~h}$. The absorbance was measured using a microplate reader at $450 \mathrm{~nm}$ (BioTek ELx800; BioTek Instruments, Inc.).

Colony formation assay. Following transfection for $48 \mathrm{~h}, \mathrm{RCC}$ cells were cultured in 6 -well plates $\left(5 \times 10^{4}\right.$ cells $\left./ \mathrm{ml}\right)$ at $37^{\circ} \mathrm{C}$ for 12 days. Subsequently, cells were washed twice with PBS, fixed in $4 \%$ paraformaldehyde for $20 \mathrm{~min}$ at room temperature, stained using Giemsa stain for $10 \mathrm{~min}$ at room temperature, and subsequently, the colonies ( $>50$ cells/colony) in the wells were counted and imaged using a fluorescence microscope (Olympus Corp).

Cell cycle and apoptosis analysis. A total of $5 \times 10^{5}$ cells were collected and centrifuged $\left(300 \mathrm{x} \mathrm{g}\right.$ for $5 \mathrm{~min}$ at $\left.4^{\circ} \mathrm{C}\right)$. Cell pellets were washed and resuspended in a solution consisting $400 \mu 1$ propidium iodide (PI), $100 \mu 1 \mathrm{RNase}$ A and permeabilization solution (Nanjing KeyGen Biotech Co., Ltd.) for $30 \mathrm{~min}$ at $4^{\circ} \mathrm{C}$ in the dark. Cell cycle analysis was performed using flow cytometry (FACSCalibur ${ }^{\mathrm{TM}}$; BD Biosciences). Cell apoptosis was measured using an Annexin V-FITC/PI Apoptosis Detection kit I (Nanjing KeyGen Biotech Co., Ltd.) according to the manufacturer's protocol and assessment was performed using flow cytometry (FACSCalibur ${ }^{\mathrm{TM}}$; BD Biosciences).

Terminal deoxynucleotidyl transferase deoxyuridine triphosphate nick end labelling (TUNEL) assay. Following transfection for $72 \mathrm{~h}$, RCC cells were fixed using $4 \%$ paraformaldehyde for $30 \mathrm{~min}$ at room temperature and subsequently washed using cold PBS. Cells were permeabilized using $1 \%$ Triton X-100 for $15 \mathrm{~min}$ and washed three times in PBS. 

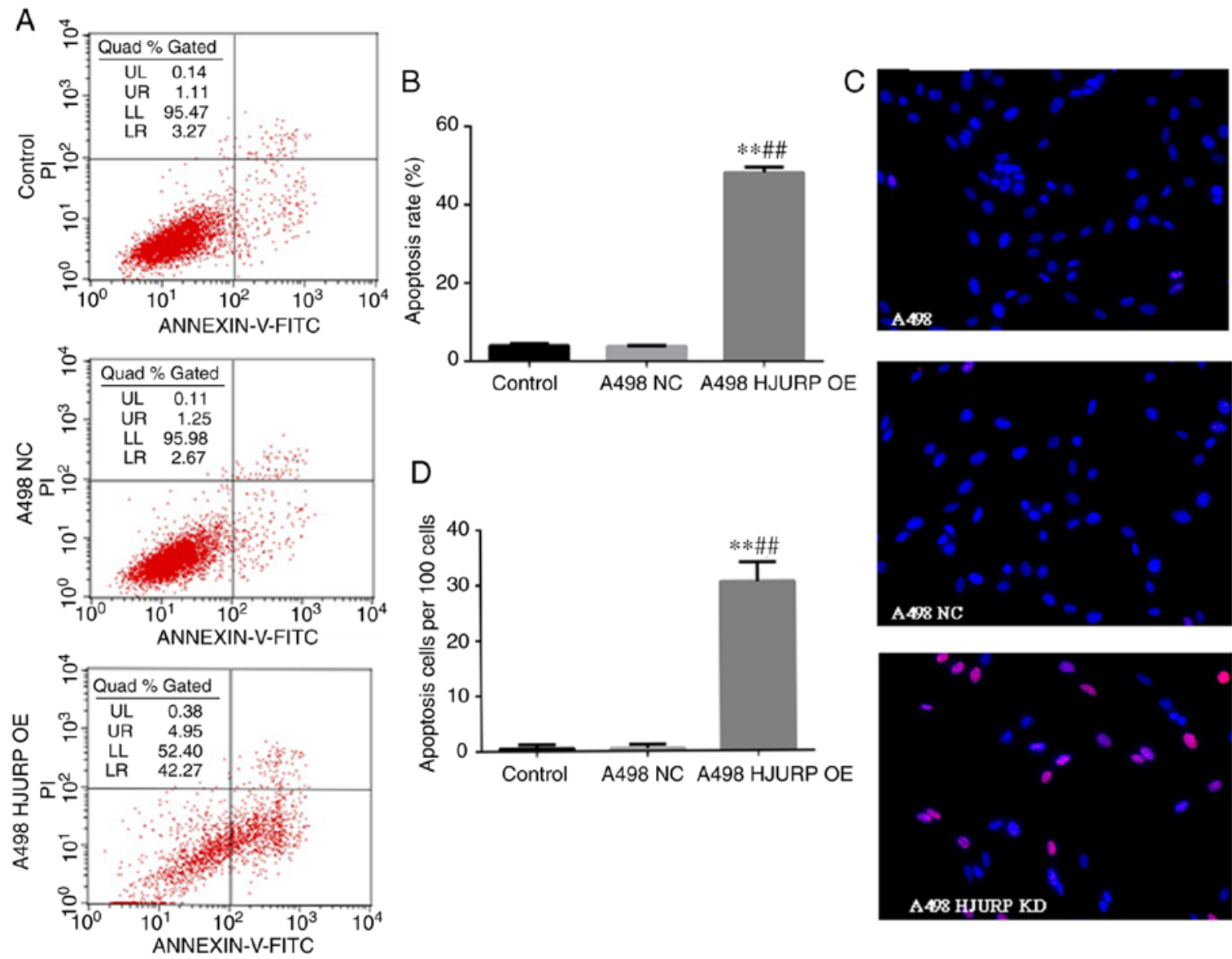

Figure 3. Apoptosis in renal cell carcinoma cells is increased by HJURP. (A) A498 cells were transfected with control-vector or an HJURP overexpression vector for $72 \mathrm{~h}$. Annexin V-FITC/PI staining and flow cytometry were used to quantify cell apoptosis. (B) Apoptotic rate (\%) in the NC group, HJURP-OE group and A498 cells. (C) Apoptosis (red) was detected using a TUNEL-assay in A498, NC and HJURP-OE cells. DAPI (blue) was used to stain the nuclei. (D) Apoptosis was significantly increased in the HJURP-OE cells compared with the control group. ${ }^{* *} \mathrm{P}<0.01$ vs. control and ${ }^{\# \#} \mathrm{P}<0.01$ vs. A498 NC. HJURP, Holliday junction recognition protein; OE, overexpression; NC, negative control; PI, propidium iodide; UL, upper left; LL lower left; UR, upper right; LR, lower right.

Analysis of apoptosis was performed using a TUNEL assay (cat. no. KGA7061; Nanjing KeyGen Biotech Co., Ltd.) according to the manufacturer's protocol. Nuclear staining was performed using $100 \mu \mathrm{l}$ DAPI for $5 \mathrm{~min}$ at room temperature, followed by washing with PBS. Cells were imaged using a fluorescence microscope (magnification, x200) and counted using a manual cell counter.

Statistical analysis. Values are expressed as the mean \pm standard deviation of three experimental repeats. Expression levels between RCC and adjacent paracancerous renal tissue samples were analyzed by a parametric paired t-test. One-way analysis of variance followed by the least significant difference test was used to analyze the values for each condition/group. Analysis was performed using SPSS version 17.0 (SPSS, Inc.). $\mathrm{P}<0.05$ was considered to indicate a statistically significant difference.

\section{Results}

HJURP expression is downregulated in RCC vs. paracancerous tissues. mRNA expression levels of HJURP in 15 pairs of RCC samples and the adjacent matching tissues were analyzed using RT-qPCR. The results indicated that HJURP expression was downregulated in RCC tissues compared with that in adjacent normal tissue samples (Fig. 1A). Similar results were obtained at the protein expression level, where HJURP was indicated to be downregulated in the RCC tissues compared with the matched normal tissues (Fig. 1B). Furthermore, HJURP protein and mRNA expression levels in the RCC cell lines were downregulated compared with those in renal tubular epithelial cells (Fig. 1C and D).

Reduced HJURP expression increases proliferation and viability of RCC cells. For subsequent in vitro experiments, the A498 cell line was used, as the endogenous expression levels of HJURP were lower than those of the other cell lines. The A498 cells were transfected with a pcDNA3.1(+) vector containing an HJURP transcript and successful upregulation was confirmed using RT-qPCR and western blot analysis at $72 \mathrm{~h}$ after transfection (Fig. $2 \mathrm{~A}$ and $\mathrm{B}$ ). Immunofluorescence staining suggested that the protein expression levels of HJURP were also significantly increased in the HJURP-transfected cells (Fig. 2C), further confirming the successful establishment of an HJURP overexpression cell line. A CCK-8 assay and colony formation assay indicated that A498 cells overexpressing HJURP exhibited reduced viability and colony formation compared with the empty vector-transfected cells 
A
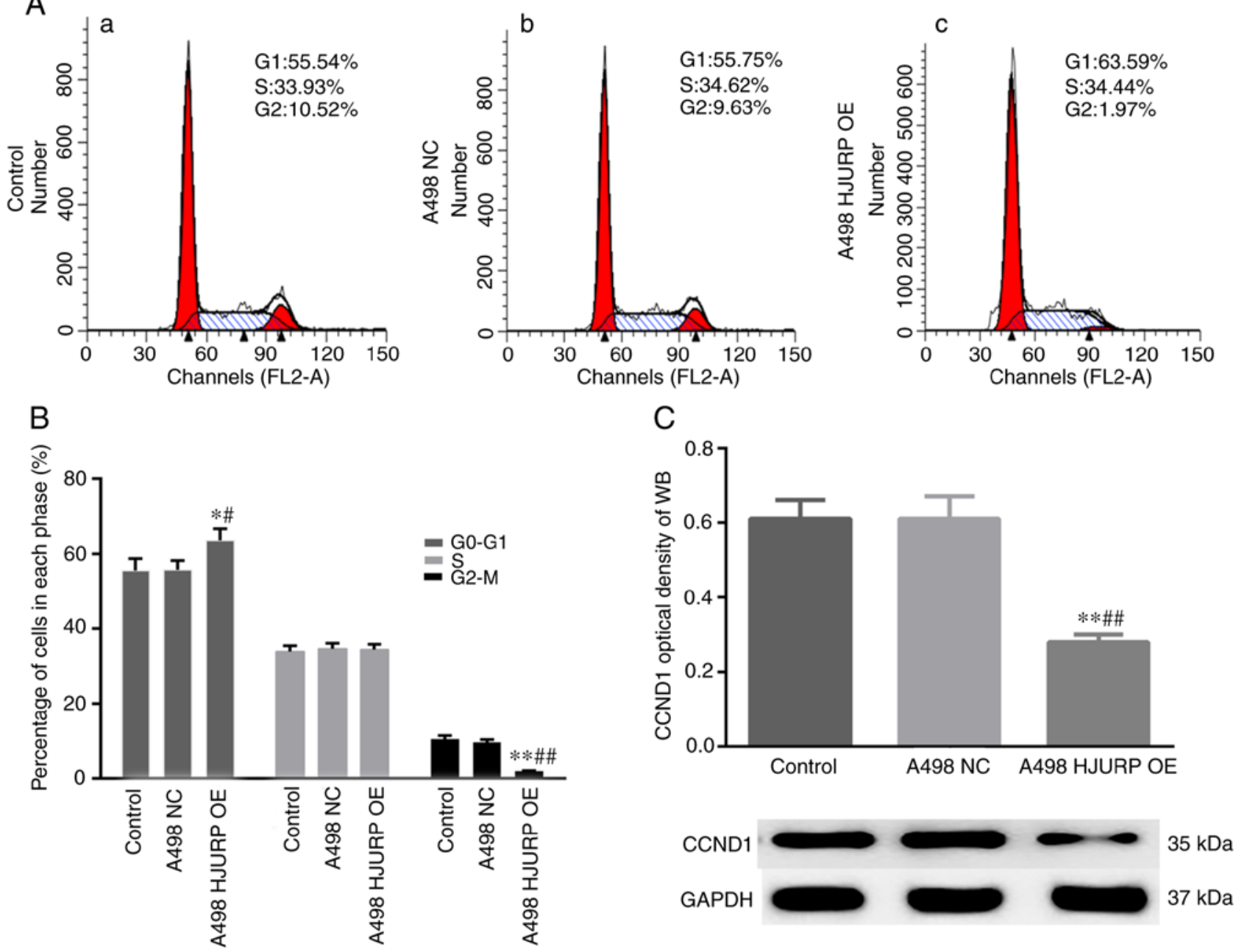

Figure 4. Upregulation of HJURP induced cell cycle arrest at G0/G1 phase in A498 cells. (A) Detection of the cell cycle distribution in (a) A498 control cells, (b) NC group and (c) HJURP-OE group. (B) Quantitative analysis of cell cycle distribution in the transfected cells. (C) CCND1 protein expression was decreased in the HJURP-OE group. ${ }^{*} \mathrm{P}<0.05,{ }^{* *} \mathrm{P}<0.01$ vs. control and ${ }^{\#} \mathrm{P}<0.05,{ }^{* \#} \mathrm{P}<0.01$ vs. A498 NC. WB, western blot; HJURP, Holliday junction recognition protein; OE, overexpression; NC, negative control; CCND1, Cyclin D1.
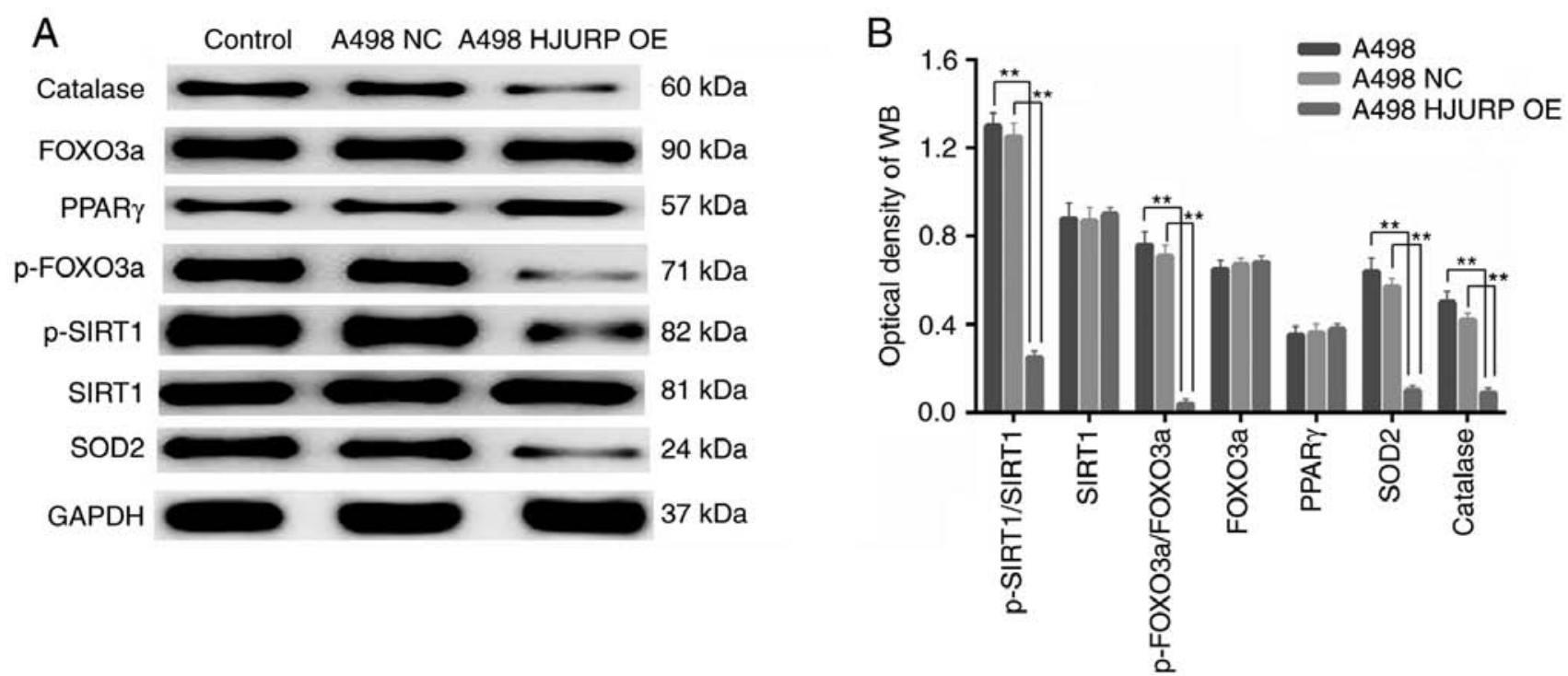

Figure 5. Overexpression of HJURP increases ROS stress in renal cell carcinoma cells. (A) Expression of proteins associated with ROS status in the (a) A498 control cells, (b) NC group and (c) HJURP-OE group. (B) Densitometry analysis indicated that the expression of ROS-associated proteins was significantly increased in the HJURP-OE group. "P $<0.05,{ }^{* *} \mathrm{P}<0.01$ as indicated. WB, western blot; HJURP, Holliday junction recognition protein; ROS, reactive oxygen species; OE, overexpression; NC, negative control; PPAR, peroxisome proliferator-activated receptor; p-FOXO3, phosphorylated forkhead box O3; SIRT1, sirtuin 1 ; SOD, superoxide dismutase. 
(Fig. 2D-G). Taken together, these results suggest that HJURP inhibits RCC in vitro.

HJURP overexpression in A498 cells increases apoptosis. As the growth of HJURP-overexpressing A498 cells was significantly reduced, the apoptotic status of the RCC cells was also assessed. The ratio of the cells in early apoptosis in the HJURP-overexpressing A498 cells was significantly increased compared with that in the empty vector-transfected cells (Fig. 3A and B). Furthermore, a TUNEL assay confirmed total apoptosis results (Fig. 3C and D).

HJURP overexpression results in cell cycle arrest at the G0/G1 phase. Changes in the cell cycle were assessed using flow cytometry. The results suggested that the proportion of cells in G0/G1 phase was significantly increased and the ratio of cells at the $\mathrm{G} 2 / \mathrm{M}$ phase was significantly decreased in the HJURP-overexpressing cells (Fig. 4A and B). Furthermore, CCND1 expression was decreased in the HJURP-overexpressing cells compared with the empty vector-transfected control cells (Fig. 4C).

Upregulation of HJURP increases ROS stress in A498 cells. Catalase and SOD2 protein expression levels, both of which are associated with the antioxidant response and ROS metabolism, were significantly decreased in the HJURP-overexpressing cells compared with the control cells (Fig. 5A). In addition, the levels of $\mathrm{p}$-SIRT1/total (t)-SIRT1 were decreased in the HJURP-overexpressing cells compared with the control cells. Furthermore, the p-FOXO3a/t-FOXO3a ratio was decreased in the HJURP-overexpressing cells (Fig. 5B). All of these results suggest that upregulation of HJURP induced oxidative stress in RCC cells via deactivation of PPAR $\gamma / \mathrm{SIRT} 1$ and downstream FOXO3a signaling.

\section{Discussion}

$\mathrm{RCC}$ is a life-threatening disease with a high rate of morbidity and mortality. There are several high-risk factors, including hypertension, obesity, smoking and chronic kidney disease, associated with the development of $\operatorname{RCC}(33,34)$. Patients with RCC are frequently diagnosed with distant metastases, at which point surgical removal is not a viable option. Thus, there is an urgency for novel accurate diagnostic and therapeutic biomarkers to improve individualized treatments and increase survival. HJURP has been demonstrated to serve as a key chaperone of CENP-A, which is involved in nucleosome assembly, and has been reported to serve a key role in different types of cancer, which contributes to promoting hepatocellular carcinoma proliferation and dysregulating the cell cycle and ROS metabolism in bladder cancer $(15,16,35)$.

In the present study, the role of HJURP in RCC was determined. The expression of HJURP was downregulated at the mRNA and protein expression levels in RCC cell lines and tissues. This result is in contrast with studies on other types of cancer (4,14-16), suggesting that the specific role of HJURP varies and is tissue-dependent, and may be associated with organ specificity, or highlights the possibility that HJURP may exert its effects on different target genes in different tissues (36-38). In the present study, overexpression of HJURP in RCC cells reduced colony formation and cell growth. Furthermore, the apoptotic rate of HJURP-overexpressing RCC cells was significantly higher compared with that in the respective controls. Thus, it was hypothesized that HJURP may regulate the cell cycle in RCC cells.

To further investigate the mechanism underlying the increased apoptosis induced by overexpression of HJURP, the expression of ROS-associated proteins was assessed and it was demonstrated that their expression was downregulated when HJURP expression was increased, and this may have been associated with apoptosis, cell cycle regulation and oxidative stress $(22,39-41)$. These results suggest that downregulation of HJURP in RCC cells disrupted homeostasis of ROS metabolism, resulting in oxidative modification of lipids, proteins or DNA, followed by apoptosis induced by oxidative stress (23). Thus, the increased apoptotic rate in RCC cells induced by the increase in HJURP expression may be associated with oxidative stress and ROS-associated pathways.

The PPAR $\gamma /$ SIRT1 feedback loop is closely associated with the oxidative stress response, cell cycle regulation and apoptosis $(25,42)$. These two proteins may be associated with the regulation of cell apoptosis, cell cycle progression and ROS metabolism. In the present study, HJURP overexpression in RCC cells decreased the ratio of p-SIRT1/t-SIRT1 significantly. Cell cycle arrest at the G0/G1 phase was observed, accompanied with a decrease in the expression of CCND1 protein. CCND1 is associated with cell cycle progression from the G0/G1 to the Sphase (43-45).

In conclusion, HJURP downregulation increased the proliferation of RCC cells and overexpression of HJURP inhibited RCC cell proliferation and promoted apoptosis. HJURP may be involved in the regulation of ROS metabolism and thus contributes to the progression of RCC. Taken together, these results suggest that HJURP may be a novel potential molecular therapeutic target for the treatment of RCC and further investigation into its suitability as a biomarker is warranted.

\section{Acknowledgements}

Not applicable.

\section{Funding}

The present study was supported by National Natural Science Foundation of China (grant no. 31800680).

\section{Availability of data and materials}

The datasets used and/or analyzed during the current study are available from the corresponding author on reasonable request.

\section{Authors' contributions}

KW and ZLZ designed the study; ZLZ, JSY and ZSC performed the experiments and analyzed the data; KW and ZLZ participated in the analysis of clinical specimens. JSY and ZLZ wrote the manuscript. KW and ZLZ revised the manuscript. All authors have read the manuscript and approved its submission. 


\section{Ethics approval and consent to participate}

All patients provided written informed consent. The Medical Ethics Committee at the Affiliated Hospital of Qingdao University (Qingdao, China) approved the use of human RCC tissue samples for protein analysis and RNA extraction (approval no. 201801), and all experiments involving the RCC tissue samples were performed in accordance with the criteria approved by the Ethics Committee.

\section{Patient consent for publication}

Not applicable.

\section{Competing interests}

The authors declare that they have no competing interests.

\section{References}

1. Siegel RL, Miller KD and Jemal A: Cancer statistics, 2018. CA Cancer J Clin 68: 7-30, 2018

2. Capitanio U and Montorsi F: Renal cancer. Lancet 387: 894-906, 2016.

3. Wei W, Lv Y, Gan Z, Zhang Y, Han X and Xu Z: Identification of key genes involved in the metastasis of clear cell renal cell carcinoma. Oncol Lett 17: 4321-4328, 2019.

4. Kato T, Sato N, Hayama S, Yamabuki T, Ito T, Miyamoto M, Kondo S, Nakamura Y and Daigo Y: Activation of holliday junction recognizing protein involved in the chromosomal stability and immortality of cancer cells. Cancer Res 67: 8544-8553, 2007.

5. Liu C and Mao Y: Diaphanous formin mDia2 regulates CENP-A levels at centromeres. J Cell Biol 213: 415-424, 2016.

6. Tachiwana H, Muller S, Blumer J, Klare K, Musacchio A and Almouzni G: HJURP involvement in de novo CenH3 (CENP-A) and CENP-C recruitment. Cell Rep 11: 22-32, 2015.

7. Perpelescu M, Hori T, Toyoda A, Misu S, Monma N, Ikeo K, Obuse C, Fujiyama A and Fukagawa T: HJURP is involved in the expansion of centromeric chromatin. Mol Biol Cell 26: $2742-2754,2015$.

8. Zhao H, Winogradoff D, Bui M, Dalal Y and Papoian GA: Promiscuous histone mis-assembly is actively prevented by chaperones. J Am Chem Soc 138: 13207-13218, 2016.

9. Mellone BG, Zhang W and Karpen GH: Frodos found: Behold the CENP-A 'Ring' bearers. Cell 137: 409-412, 2009.

10. Dunleavy EM, Roche D, Tagami H, Lacoste N, Ray-Gallet D, Nakamura Y, Daigo Y, Nakatani Y and Almouzni-Pettinotti G: HJURP is a cell-cycle-dependent maintenance and deposition factor of CENP-A at centromeres. Cell 137: 485-497, 2009.

11. Foltz DR, Jansen LE, Bailey AO, Yates JR III, Bassett EA, Wood S, Black BE and Cleveland DW: Centromere-specific assembly of CENP-a nucleosomes is mediated by HJURP. Cell 137: 472-484, 2009.

12. Shuaib M, Ouararhni K, Dimitrov S and Hamiche A: HJURP binds CENP-A via a highly conserved N-terminal domain and mediates its deposition at centromeres. Proc Natl Acad Sci USA 107: 1349-1354, 2010.

13. Valente V, Serafim RB, de Oliveira LC, Adorni FS, Torrieri R, Tirapelli DP, Espreafico EM, Oba-Shinjo SM, Marie SK, Paçó-Larson ML, et al: Modulation of HJURP (Holliday Junction-Recognizing Protein) levels is correlated with glioblastoma cells survival. PLoS One 8: e62200, 2013.

14. Montes de Oca R, Gurard-Levin ZA, Berger F, Rehman H, Martel E, Corpet A, de Koning L, Vassias I, Wilson LO, Meseure D, et al: The histone chaperone HJURP is a new independent prognostic marker for luminal A breast carcinoma. Mol Oncol 9: 657-674, 2015 .

15. Cao R, Wang G, Qian K, Chen L, Qian G, Xie C, Dan HC, Jiang W, Wu M, Wu CL, et al: Silencing of HJURP induces dysregulation of cell cycle and ROS metabolism in bladder cancer cells via PPAR $\gamma$-SIRT1 feedback loop. J Cancer 8: 2282-2295, 2017.
16. Chen T, Huang H, Zhou Y, Geng L, Shen T, Yin S, Zhou L and Zheng S: HJURP promotes hepatocellular carcinoma proliferation by destabilizing p21via the MAPK/ERK1/2 and AKT/ GSK3 $\beta$ signaling pathways. J Exp Clin Cancer Res 37: 193, 2018.

17. Bravaccini S, Tumedei MM, Scarpi E, Zoli W, Rengucci C, Serra L, Curcio A, Buggi F, Folli S, Rocca A, et al: New biomarkers to predict the evolution of in situ breast cancers. Biomed Res Int 2014: 159765, 2014.

18. Coates P, Dewar J and Thompson AM: At last, a predictive and prognostic marker for radiotherapy? Breast Cancer Res 12: 106, 2010.

19. Hu Z, Huang G, Sadanandam A, Gu S, Lenburg ME, Pai M, Bayani N, Blakely EA, Gray JW and Mao JH: The expression level of HJURP has an independent prognostic impact and predicts the sensitivity to radiotherapy in breast cancer. Breast Cancer Res 12: R18, 2010.

20. Belfiore A, Genua M and Malaguarnera R: PPAR-g agonists and their effects on IGF-I receptor signaling: Implications for cancer. PPAR Res 2009: 830501, 2009.

21. Berger J and Moller DE: The mechanisms of action of PPARs. Annu Rev Med 53: 409-435, 2002.

22. Vecchione G, Grasselli E, Voci A, Baldini F, Grattagliano I, Wang DQ, Portincasa P and Vergani L: Silybin counteracts lipid excess and oxidative stress in cultured steatotic hepatic cells. World J Gastroenterol 22: 6016-6026, 2016.

23. Li S, Zhou Q, He H, Zhao Y and Liu Z: Peroxisome proliferator-activated receptor $g$ agonists induce cell cycle arrest through transcriptional regulation of Kruppel-like factor 4 (KLF4). J Biol Chem 288: 4076-4084, 2013.

24. Yamamoto Y, Ono T, Dhar DK, Yamanoi A, Tachibana M, TanakaT and NagasueN: Role of peroxisome proliferator-activated receptor-gamma (PPARgamma) during liver regeneration in rats. J Gastroenterol Hepatol 23: 930-937, 2008.

25. Han L, Zhou R, Niu J, McNutt MA, Wang P and Tong T: SIRT1 is regulated by a PPAR $\{\mathrm{g}\}$-SIRT1 negative feedback loop associated with senescence. Nucleic Acids Res 38: 7458-7471, 2010.

26. Picard F, Kurtev M, Chung N, Topark-Ngarm A, Senawong T, Machado De Oliveira R, Leid M, McBurney MW and Guarente L: Sirt1 promotes fat mobilization in white adipocytes by repressing PPAR-gamma. Nature 429: 771-776, 2004.

27. Vaziri H, Dessain SK, Ng Eaton E, Imai SI, Frye RA, Pandita TK, Guarente L and Weinberg RA: hSIR2 (SIRT1) functions as an NAD-dependent p53 deacetylase. Cell 107: 149-159, 2001.

28. Clark MJ, Homer N, O'Connor BD, Chen Z, Eskin A, Lee H, Merriman B and Nelson SF: U87MG decoded: The genomic sequence of a cytogenetically aberrant human cancer cell line. PLoS Genet 6: e1000832, 2010.

29. Pleasance ED, Cheetham RK, Stephens PJ, McBride DJ, Humphray SJ, Greenman CD, Varela I, Lin ML, Ordóñez GR, Bignell GR, et al: A comprehensive catalogue of somatic mutations from a human cancer genome. Nature 463: 191-196, 2010.

30. Stephens PJ, McBride DJ, Lin ML, Varela I, Pleasance ED, Simpson JT, Stebbings LA, Leroy C, Edkins S, Mudie LJ, et al: Complex landscapes of somatic rearrangement in human breast cancer genomes. Nature 462: 1005-1010, 2009.

31. Eble JN, Sauter G, Epstein JI and Sesterhenn IA: Pathology and genetics of tumours of the urinary system and male genital organs. 1st edition. IARC Press, Lyon, 12-43, 2004.

32. Livak KJ and Schmittgen TD: Analysis of relative gene expression data using real-time quantitative PCR and the 2(-Delta Delta C(T)) method. Methods 25: 402-408, 2001.

33. Capitanio U, Bensalah K, Bex A, Boorjian SA, Bray F, Coleman J, Gore JL, Sun M, Wood C and Russo P: Epidemiology of renal cell carcinoma. Eur Urol 75: 74-84, 2019.

34. Chow WH, Dong LM and Devesa SS: Epidemiology and risk factors for kidney cancer. Nat Rev Urol 7: 245-257, 2010.

35. Hu B, Wang Q, Wang Y, Chen J, Li P and Han M: Holliday junction-recognizing protein promotes cell proliferation and correlates with unfavorable clinical outcome of hepatocellular carcinoma. Onco Targets Ther 10: 2601-2607, 2017.

36. Wei Y, Ouyang GL, Yao WX, Zhu YJ, Li X, Huang LX, Yang XW and Jiang WJ: Knockdown of HJURP inhibits non-small cell lung cancer cell proliferation, migration, and invasion by repressing Wnt $/ \beta$-catenin signaling. Eur Rev Med Pharmacol Sci 23: 3847-3856, 2019.

37. Chen YF, Liang YX, Yang JA, Yuan DZ, Li J, Zheng SS, Wan YP, Wang B, Han ZD and Zhong WD: Upregulation of holliday junction recognition protein predicts poor prognosis and biochemical recurrence in patients with prostate cancer. Oncol Lett 18: 6697-6703, 2019. 
38. Serafim RB, Cardoso C, Di Cristofaro LFM, Pienna Soares C, Araújo Silva W Jr, Espreafico EM, Paçó-Larson ML, Price BD and Valente V: HJURP knockdown disrupts clonogenic capacity and increases radiation-induced cell death of glioblastoma cells. Cancer Gene Ther 27: 319-329, 2020.

39. Liu J, Zhou J, Wu Z, Wang X, Liu L and Yao C: Cyanidin 3-O-beta-glucoside ameliorates ethanol-induced acute liver injury by attenuating oxidative stress and apoptosis: The role of SIRT1/FOXO1 signaling. Alcohol Clin Exp Res 40: 457-466, 2016.

40. Ruan Y, Dong C, Patel J, Duan C, Wang X, Wu X, Cao Y, Pu L, Lu D, Shen T and Li JL: SIRT1 suppresses doxorubicin-induced cardiotoxicity by regulating the oxidative stress and p38MAPK pathways. Cell Physiol Biochem 35: 1116-1124, 2015.

41. Circu ML and Aw TY: Reactive oxygen species, cellular redox systems, and apoptosis. Free Radic Biol Med 48: 749-762, 2010.
42. Wang Y, Liang X, Chen Y and Zhao X: Screening SIRT1 activators from medicinal plants as bioactive compounds against oxidative damage in mitochondrial function. Oxid Med Cell Longev 2016: 4206392, 2016.

43. Wang Q, He G, Hou M, Chen L, Chen S, Xu A and Fu Y: Cell cycle regulation by alternative polyadenylation of CCND1. Sci Rep 8: 6824, 2018.

44. Guardavaccaro D, Corrente G, Covone F, Micheli L, D'Agnano I, Starace G, Caruso M and Tirone F: Arrest of G(1)-S progression by the p53-inducible gene PC3 is Rb dependent and relies on the inhibition of cyclin D1 transcription. Mol Cell Biol 20: $1797-1815,2000$.

45. Musgrove EA, Lee CS, Buckley MF and Sutherland RL: Cyclin D1 induction in breast cancer cells shortens G1 and is sufficient for cells arrested in G1 to complete the cell cycle. Proc Natl Acad Sci USA 91: 8022-8026, 1994. 